\title{
Kounis syndrome: A new etiologic factor of myocardial infarction with non-obstructive coronary arteries - Author response
}

\author{
Javier Lopez Pais ${ }^{1,2}$, Barbara Izquierdo Coronel ${ }^{1}$, Maria Jesus Espinosa Pascual ${ }^{1}$, \\ David Galán Gil ${ }^{1}$, Blanca Alcón Durán ${ }^{1}$, Joaquin Jesus Alonso Martin ${ }^{1}$ \\ ${ }^{1}$ Department of Cardiology, University Hospital of Getafe, Spain \\ ${ }^{2}$ Department of Cardiology, University Hospital Complex of Santiago de Compostela, Spain
}

It is an honour that Kounis et al. [1] decided to write a letter to complete this report published in "Cardiology Journal" a few months ago [2]. It was also a pleasure to learn more about this interesting entity directly from Dr. Kounis.

Given the latest research on myocardial infarction with non-obstructive coronary arteries (MINOCA) patients and following the recommendations of the European Society of Cardiology (ESC), this Working Group position paperon the present topic [3], it is extremely important to perform an etiological diagnosis that identifies the underlying cause in order to optimize treatment.

Within these cases, the scope of endothelial dysfunction and microcirculation ischemia are the subject of many current studies.

Immunomodulation and cardiovascular disease is a fascinating issue which is taken as more of a protagonist on a daily basis. Two outstanding studies have recently been published concerning this field. Kwong et al. [4] have shown the link between the flu and myocardial infarction, and the CANTOS study shows the impact of immunomodulatory treatment on cardiovascular risk [5]; as did the present group in an abstract presented at the ESC Congress [6].

Anaphylaxis is a stressful situation which may lead to different scenarios, including takotsubo syndrome and vasospasm, both potential underlying causes of MINOCA.

Kounis syndrome may have a place in MINOCA etiology because of its main physiopathological mechanism, being that this syndrome is described as an concurrence of acute coronary syndrome with conditions associated with mast cell activation including allergic or hypersensitivity, anaphylactic or anaphylactoid insults $[7,8]$.

However, in these cases were an allergy insult MINOCA concurs, it is hard to say whether the myocardial injury is caused by the release of inflammatory mediators itself, or if it is caused by other coexisting conditions.

In this MINOCA series [2], there was 1 patient who had a MINOCA after an allergic insult. It may have fulfilled criteria of Kounis syndrome type I (patients with normal coronary arteries in whom an acute allergic insult leads to coronary artery spasm with infarction with positive cardiac biomarkers). Nevertheless, it could not demonstrated that the presence of a vasospasm and the mechanism underlying the acute event of that patient was considered a type II myocardial infarction caused by tachycardia and hypertension after epinephrine.

As had been expressed, it was hard to decide which etiological group these patients belonged to, because many of the patients with anaphylactic reactions receive epinephrine, which could cause angina, electrocardiogram abnormalities, and even troponin elevation itself. In addition to that, an allergic episode in itself can cause myocardial damage due to coronary hypoperfusion in the context of reduced cardiac output derived from severe systemic vasodilation. In some cases, even takotsubo syndrome due to a stressful situation could be an explanation.

Regarding treatment and secondary prevention, the most important in these patients is to

Address for correspondence: Javier López Pais, MD, Secretaría del Servicio de Cardiología, 2ª planta, Control 2C. Hospital Universitario de Getafe, Carretera de Toledo Km 12.5, 28901, Getafe, Madrid, Spain, tel: 0034639656529.

e-mail: javierlopezpais@gmail.com

Received: 27.07.2018 Accepted: 27.07.2010 
take the allergy trigger into account, because special tests need to be run. Nowadays, there is insufficient evidence to decide upon the indication of treatment with mast cell surface membrane protectors. Given this, the present patient was referred to the Immunology Department and ESC-guidelines based treatment was prescribed.

It was believed that with these types of studies, more could be learned about the effects of proinflammatory conditions and their effect on myocardial cells, not only to treat cardiovascular diseases but also to improve their primary and secondary prevention.

The efforts of Dr. Kounis are much appreciated in describing a concrete entity that each professional should take into account when treating patients, and it is hoped that all can continue with the study of allergy and inflammation as emerging risk factors for coronary artery disease.

\section{Conflict of interest: None declared}

\section{References}

1. Kounis NG, Koniari I, Soufras D, et al. Kounis syndrome: An additional etiologic factor of myocardial infarction with non- -obstructive coronary arteries. Cardiol J. 2018, 25(5): 648-649, doi: 10.5603/CJ.2018.0132.

2. Lopez Pais JL, Izquierdo Coronel B, Galán Gil D, et al. Psycho-emotional disorders as incoming risk factors for myocardial infarction with non-obstructive coronary arteries. Cardiol J. 2018; 25(1): 24-31, doi: 10.5603/CJ.a2017.0139, indexed in Pubmed: 29240964.

3. Agewall S, Beltrame JF, Reynolds HR. ESC working group position paper on myocardial infarction with non-obstructive coronary arteries. Eur Heart J. 2017; 38(3): 143-153.

4. Kwong JC, Schwartz KL, Campitelli MA, et al. Acute Myocardial Infarction after Laboratory-Confirmed Influenza Infection. N Engl J Med. 2018; 378(4): 345-353, doi: 10.1056/NEJMoa1702090, indexed in Pubmed: 29365305.

5. Ridker PM, Everett BM, Thuren T, et al. Antiinflammatory Therapy with Canakinumab for Atherosclerotic Disease. N Engl J Med. 2017; 377(12): 1119-1131, doi: 10.1056/NEJMoa1707914, indexed in Pubmed: 28845751.

6. Lopez-Pais J, Izquierdo-Coronel B, Galan-Gil D, et al. P1798. May be inflammatory charge a new risk factor for myocardial infarction with non-obstructive coronary arteries? Eur Heart J. 2017; 38(suppl 1), doi: 10.1093/eurhearti/ehx502.p1798.

7. Kounis NG, Zavras GM. Histamine-induced coronary artery spasm: the concept of allergic angina. Br J Clin Pract. 1991; 45(2): 121-128, indexed in Pubmed: 1793697.

8. Kounis NG. Kounis syndrome (allergic angina and allergic myocardial infarction): a natural paradigm? Int J Cardiol. 2006; 110(1): 7-14, doi: 10.1016/j.ijcard.2005.08.007, indexed in Pubmed: 16249041 . 